\title{
Johtamisen viestintähaasteet tietoperustaisessa työssä
}

\author{
Maijastiina Rouhiainen-Neunhäuserer
}

Lectio praecursoria puheviestinnän väitöskirjaksi tarkoitetun tutkimuksen Johtajan vuorovaikutusosaaminen ja sen kehittyminen. Johtamisen viestintähaasteet tietoperustaisessa organisaatiossa tarkastustilaisuudessa Jyväskylän yliopistossa 20.11.2009. Vastaväittäjänä toimi professori Riitta Viitala (Vaasan yliopisto) ja kustoksena professori Tarja Valkonen.

Ympäristö, jossa työskentelemme, on yhä tietointensiivisempi. Tietoyhteiskunnassa työntekijöiltä edellytetään yhä syvällisempää osaamista, ja työskentely perustuu abstrakteille, käsitteellisille prosesseille. Työn tuloksena eivät ole niinkään konkreettiset, käsin kosketettavat lopputuotteet vaan ennemminkin innovaatiot, uusi tieto tai pitkälle kehitetyt palvelut. Tietoyhteiskunnalle tyypillisissä organisaatioissa työntekijöistä suuri osa on korkeasti koulutettuja asiantuntijoita, ja työn keskeisiä välineitä ovat työntekijöiden luovuus, osaaminen ja tieto. Väitöskirjatutkimukseni kiinnittyy tällaisen tietoperustaisen työn johtamiseen. Tarkastelun kohteena on johtajan vuorovaikutusosaaminen tietoperustaisessa organisaatiossa ja sen kehittyminen viestintäkoulutuksessa.

Niin puheviestinnässä kuin muillakin tieteenaloilla sekä laajemmalla yhteiskunnallisella tasolla on käyty keskustelua työelämän muutoksista ja muutoksien mukanaan tuomista johtamisen haasteista. Näissä keskusteluissa korostetaan viestinnän ja vuorovaikutusosaamisen merkitystä. Vuorovaikutusosaamisen ja -taidon käsitteet nousevat esiin esimerkiksi erilaisissa johtamisen osaamiskuvauksissa ja -vaatimuksissa. Johtamisviestintää on tutkittu laajasti ja tutkimuksissa on jäsennetty myös johtajan viestintään liittyvää osaamista. Viestinnän ja vuorovaikutusosaamisen käsitteet ovat kuitenkin monimerkityksisiä eikä johtamiskompetenssien jäsennyksissä ole tähän mennessä tarkasteltu nimenomaan johtajan ja johdettavan väliselle vuorovaikutussuhteelle perustuvaa vuorovaikutusosaamista. Havaintoni perusteella ilmiötä ei ole myöskään teoreettisesti jäsennetty tietoperustaisen organisaation kontekstissa eikä asiasta ole empiiristä tutkimusaineistoa. Viestintä on kuitenkin yhä tärkeämmässä osassa johtamista: Keskeinen osa tietoperustaista työtä on tiedon käyttö, uuden tiedon luonti ja organisaation työntekijöiden välinen vaihdanta. Johtajan tehtävänä puolestaan on tukea alaistensa työskentelyä ja edistää heidän keskinäistä vuorovaikutustaan.

Koska tietoperustainen työ eroaa luonteeltaan perinteisemmästä, hallinnollisin käytännöin järjestetystä tai toimintakeskeisestä työstä, voidaan olettaa, että 
myös tietoperustaisessa organisaatiossa työskentelevän johtajan vuorovaikutustilanteet ovat toisenlaisia. Erilaiset johtamisviestintätilanteet edellyttävät puolestaan erilaista vuorovaikutusosaamista. Halusin saavuttaa tutkimuksessani ymmärryksen siitä, millaisia muotoja, tapoja ja piirteitä johtamisviestintään liittyy tietoperustaista työtä johdettaessa ja millaisia osaamistarpeita nämä nostavat esiin. Tavoitteenani oli teoreettisesti jäsentää sitä, mitä johtajan vuorovaikutusosaaminen on tietoperustaisessa organisaatiossa.

Tutkijoita ja työelämän toimijoita askarruttaa lisäksi johtamisen kehittäminen. Oppimisen ja kehittymisen merkitys tietoyhteiskunnassa on yhä ratkaisevammassa asemassa. Yritysten henkilöstön ja erityisesti johtajien osaamisen ja sen kehittymisen laatu on merkittävä kilpailutekijä ja jopa yritysten henkiinjäämisen edellytys. Johtamisen kehittämistoimien ja koulutusten sisällöissä painotetaan vuorovaikutusosaamista. Yleinen näkemys on, että sitä olisi paikallaan kehittää. Johtamisviestintäkoulutuksen vaikuttavuudesta ei kuitenkaan juuri ole tutkimustietoa. Jotta johtajan vuorovaikutusosaamisen kehittämiseen löydetään sekä tehokkaat että vaikuttavat keinot, tulee tutkimuksen selventää sitä, millaisia vaikutuksia viestintäkoulutuksella on koulutettavien johtajien asenteisiin, tietoihin ja taitoihin johtamisviestinnästä ja miten muodollisessa koulutuksessa opitut asiat siirtyvät johtajien käytännön työhön. Tutkimukseni kohdistuikin siihen, miten johtajan vuorovaikutusosaaminen kehittyy viestintäkoulutuksessa.

Tutkimustani voi luonnehtia tapaustutkimukseksi, sillä se toteutettiin yhdessä organisaatiossa ja yhdessä viestintäkoulutuksessa. Valitsin kohdeorganisaatioksi suomalaisen teollisen alan tutkimus- ja kehittämispalveluita tarjoavan asiantuntijaorganisaation, jonka johtajat suorittivat Johtamisen erikoisammattitutkinnon. Erikoisammattitutkintoon sisältyi viestintäkoulutusta.

Lähestyin tutkimusongelmiani laadullisesti ja pitkittäistutkimuksen tavoin. Ensiksi haastattelin 17 kohdeorganisaation esimiesasemassa toimivaa johtajaa. Nämä johtajat osallistuivat Johtamisen erikoisammattitutkinnon viestintäkoulutukseen. Selvitin sitä, miten tietoperustaisessa organisaatiossa työskentelevät johtajat käsitteellistävät ja merkityksentävät johtajan vuorovaikutusosaamista ja johtamisviestinnän osaamistarpeita. Keräsin haastatteluaineiston ennen viestintäkoulutusta.

Toiseksi selvitin fokusryhmä-keskusteluissa johtajien käsityksiä johtamisviestintäkoulutuksesta ja viestintäkoulutuksessa opitun siirrettävyydestä käytäntöön. Keskustelut käytiin kolme kuukautta viestintäkoulutuksen jälkeen. Niihin osallistui 10 johtajaa, joita olin haastatellut puolitoista vuotta aikaisemmin. Analysoin aineistoni jatkuvan vertailun mallin ja tapausten välisen vertailun menetelmän avulla.

Tutkimukseni tulokset auttavat jäsentämään ja ymmärtämään niitä viestintähaasteita, joihin nykyjohtaja törmää päivittäin työssään. Lisäksi tulosten avulla voidaan ryhmitellä uudella tapaa johtamisen kehittämisinterventioiden ja johtamisviestintäkoulutusten tavoitteita ja sisältöjä. 
Tutkimukseen osallistuneiden johtajien kuvauksissa työnsä vuorovaikutustilanteista sekä viestinnän tavoista ja muodoista ilmenevät johtamisviestinnän monet funktiot. Johtaja on vastuussa ensinnäkin organisaation toimintasuunnan, vision ja strategian merkityksentämisestä ja viestimisestä sekä alaisten sitouttamisesta niihin. Toisekseen johtajan odotetaan hankkivan tietoa niin organisaation sisällä kuin sen ulkopuolisissa verkostoissa ja välittävän tietoa eteenpäin. Kolmannekseen johtajan tulee verkottua, luoda ja ylläpitää vuorovaikutussuhteita. Neljäs johtamisviestinnän funktio liittyy työn ohjaukseen ja palautteenantoon. Viidentenä funktiona on alaisten keskinäisen vuorovaikutuksen tukeminen. Nämä tehtävät lienevät tyypillisiä missä tahansa organisaatiossa. Oli kuitenkin mielenkiintoista havaita, että haastatteluaineistossa korostuu johtamisviestinnän funktioiden erityinen luonne ja johtamisviestinnän haasteellisuus johdettaessa ja ohjattaessa tietoperustaista työtä.

Tutkimukseni tulosten perusteella johtajan vuorovaikutusosaaminen tulee ilmi johtajan ja johdettavan välisessä vuorovaikutussuhteessa, johon kohdistuu erilaisia odotuksia ja arvostuksia. Tietoperustaisen työn johtamisen viestintähaasteet liittyvät jännitteisiin odotuksiin siitä, miten etäistä ja läheistä johtamisviestinnän tulisi olla, miten osallistavaa ja johtajakeskeistä tarkoituksenmukainen ja tehokas johtamisviestintä on sekä miten varmaa ja selkeää johtamisviestintä voi epävarmassa toimintaympäristössä olla. Esittelen seuraavaksi mielenkiintoisimpia tuloksia näistä kolmesta jännitteestä.

Projektiperustaisessa työskentelyssä johtaja saattaa välillä toimia muodollisessa projektijohtajan asemassa ja välillä johdettavan henkilön kanssa tasavertaisena kollegana. Asiantuntijatieto myös helposti yksilöityy ja ikään kuin leviää pitkin organisaation matriisimaista rakennetta. Johtaja saattaa esimerkiksi joutua toimimaan esimiesasemassa sellaiselle henkilölle, jonka työn ohjauksesta hän ei ole vastuussa. Johtajan tehtävä luoda ja ylläpitää vuorovaikutusta alaisiinsa on haasteellinen myös siksi, että aikaresurssit ovat rajalliset ja hajautuneessa työssä kasvokkaisviestintä ei ole aina mahdollista. Haaste liittyy siis johtamisviestinnän etäisyyden ja läheisyyden jännitteen hallintaan.

Tutkimusalalla on tiedostettu, että tietoperustaisen organisaation potentiaali ja menestyksen avain ovat sen työntekijät ja heidän vuorovaikutteinen työskentelynsä. Tutkimustulosteni perusteella johtajan keskeisimpiä viestintätaitoja onkin ohjata kriittiseen ajatteluun tottuneita alaisia sekä itseohjautuvaa ja henkilökohtaisesti koettavaa työtä. Asiantuntija-alaisia ohjattaessa johtajalta edellytetään erityistä herkkyyttä kuunnella ja reagoida alaisten mielipiteisiin, aktiivisuutta kertoa avoimesti ja riittävästi organisaatiota koskevista päätöksistä ilman, että yrityksen strateginen kilpailuetu vaarantuu sekä korkeatasoisia perustelutaitoja vakuuttaa alaiset. Johtajan vuorovaikutusosaaminen onkin tasapainoilua sen välillä, milloin on tarkoituksenmukaista ja tehokasta viestiä johtajakeskeisesti ja milloin osallistavasti. 
Oli myös erittäin mielenkiintoista huomata, että johtajien vuorovaikutusosaamiseen kohdistuvat odotukset ovat kovin korkeita ja osin jopa idealistisia. Johtajien odotetaan kertovan vakuuttavan varmasti ja selkeäsanaisesti organisaation tulevaisuudesta. Johtajien työympäristö on kuitenkin epävarma ja dynaaminen. Johtamisviestintä ei aina ole varmaa tai selkeää vuorovaikutustilanteiden dynaamisuuden ja nopean työtahdin takia. Johtajan onkin hyvä asennoitua jatkuvasti muuttuviin tilanteisiin ikään kuin johtamisviestinnän ominaispiirteenä. Lisäksi johtajalta edellytetään rohkeaa ja avointa suhtautumista alaisten keskinäisen vuorovaikutuksen tukemiseen toimintaympäristön muutoksista ja epävarmuudesta huolimatta.

Tutkimukseni keskeisenä ja merkittävimpänä tuloksena voidaan pitää teoreettista jäsennystä siitä, miten johtajan vuorovaikutusosaamisessa tietoperustaisessa organisaatiossa on kyse nimenomaan johtamisviestinnän sekä johtajan ja johdettavan välisen vuorovaikutussuhteen jännitteiden hallinnasta. Johtajan vuorovaikutusosaaminen tietoperustaisessa organisaatiossa tarkoittaa siis sitä, että johtajalla on tietoa johtamisviestintään kohdistuvista jännitteisistä odotuksista, johtamisviestinnän haasteista ja siitä, miten jännitteitä ja haasteita voi hallita. Johtajalla on myös taitoa hallita erilaisia johtamisviestintään kohdistuvia odotuksia ja vuorovaikutuksen jännitteitä. Lisäksi johtajalta edellytetään motivaatiota viestiä ja avointa asennoitumista johtamisviestintää kohtaan, vaikka siihen liittyykin haasteita. Huomionarvoinen on myös se tulos, että johtajan ja johdettavan välisen vuorovaikutussuhteen laatuun ja luontee $\urcorner$ seen sekä johtamisviestintään vaikuttaa johtajan osaamisen lisäksi johdettavan vuorovaikutusosaaminen. Johtaminen rakentuu johtajan ja johdettavan väliselle vuorovaikutussuhteelle, jonka laatuun vaikuttaa sen molempien osapuolten vuorovaikutusosaaminen.

Näiden tutkimustulosten varaan voidaan rakentaa käytännön johtamisviestinnän malleja. Tällaisesta voi esimerkkinä mainita asiantuntijatyön ohjausmallin, jossa hyödynnetään vertaispalautetta. Teoreettisen jäsennyksen avulla on mahdollista myös tarkentaa johtajan vuorovaikutusosaamista osana ammatillisen suoriutumisen arviointikriteerejä ja palkkiojärjestelmiä.

Tutkimuksen toisena tavoitteena oli jäsentää teoreettisesti sitä, miten johtajan vuorovaikutusosaaminen kehittyy viestintäkoulutuksessa. On tärkeää huomioida, että vuorovaikutusosaamisen kehittymistä ei voida rajata ja kohdentaa ainoastaan viestintäkoulutukseen. Vuorovaikutusosaaminen voi kehittyä myös muissa kehittämistoimissa, johtajan työssä tai työn ulkopuolella.

Vaikka viestintäkoulutuksen vaikutukset eivät olekaan aina suoraviivaisia ja selkeitä, näyttäisi tutkimuksessa tarkastellulla johtamisviestintäkoulutuksella olleen vaikutusta. Johtajien käsitykset johtamisviestinnän osaamistarpeesta olivat haasteellisia ja odotukset viestintäkoulutukselle korkeita. Olikin mielenkiintoista havaita, että johtajat arvioivat viestintäkoulutusta kovin myönteisesti. Heidän mukaansa koulutuksen tuloksena oli ennen kaikkea tietojen karttuminen johtamisviestinnästä, viestintää kohtaan liittyvien asenteiden muuttumi- 
nen ja oman vuorovaikutuskäyttäytymisen arviointiin ja säätelyyn tarvittavien metakognitiivisten taitojen kehittyminen. Lisäksi koulutuksen vaikutukset ilmenivät johtamisviestinnän ja organisaation vuorovaikutuskäytäntöjen kehittämisenä.

Kovin positiivisista käsityksistä huolimatta johtajat arvioivat kriittisesti vuorovaikutustaitojensa kehittymistä viestintäkoulutuksessa. Tulkitsen tämän tarkoittavan sitä, että viestintä- ja vuorovaikutustaitojen ymmärtäminen tapahtuu toisenlaisin mekanismein kuin taitojen soveltaminen ja vahvistaminen. Viestintätaitojen ymmärtäminen ei myöskään välttämättä johda taidokkaaseen käyttäytymiseen.

Vaikka viestintä- ja vuorovaikutustaitojen kehittyminen näyttäisi vaativan aikaa, harjoittelua ja ohjausta, viestintäkoulutuksessa on tutkimukseen osallistuneiden johtajien mukaan mahdollista vastata johtamisen viestintähaasteista nouseviin osaamistarpeisiin. Ehtona tälle on se, että koulutettava, kouluttaja ja kohdeorganisaatio onnistuvat määrittämään tarpeeksi selkeästi osaamis- ja kehittämistarpeet sekä niihin sopivat koulutussisällöt ja -menetelmät.

Myös johtamisen erikoisammattitutkinnossa on potentiaalia viitekehykseksi johtajan vuorovaikutusosaamisen kehittymiselle. Haluan kuitenkin korostaa sitä, että on olennaista nostaa esiin nykyistä paremmin joustavat johtamisviestintämallit. On tähdellistä jäsentää tietoperustaisen organisaation johtamisen viestintähaasteet ja niiden hallinta osaksi näyttötutkinnon tavoitteita. Johtamisviestintäkoulutukselle tulee myös taata tarpeeksi laaja ja keskeinen osa erikoisammattitutkinnon valmennusjaksoista.

Tutkijan tehtävä on arvioida tutkimustaan myös kriittisesti ja nostaa esiin niitä seikkoja, joihin tutkimus ei vielä vastannut ja joita olisi tarpeen tarkastella jatkossa. Tavoitteenani oli jäsentää teoreettisesti sitä, mitä on johtajan vuorovaikutusosaaminen tietoperustaisessa organisaatiossa ja miten se kehittyy viestintäkoulutuksessa. Valitsemani näkökulma aiheeseen toi esiin tietoperustaisessa organisaatiossa työskentelevien johtajien käsityksiä tutkittavasta ilmiöstä. Selvitin asiaa tietoisesti johtajien näkökulmasta sen sijaan, että olisin tarkastellut alaisten käsityksiä. Katson, että johtajien vuorovaikutusosaamisen kehittymistä tulee selvittää nimenomaan koulutukseen osallistuneiden johtajien oppimiskokemuksista käsin.

Jatkossa olisi kuitenkin tärkeätä selvittää, millaisia osaamistarpeita johtajan vuorovaikutusosaamiselle nousee alaisten käsityksistä ja millaisia keskinäisiä arvostuksia, sopimuksia ja jaettuja tavoitteita johtajilla ja johdettavilla on viestinnästä. Selvittämällä sekä johtajien että alaisten käsityksiä saataisiin muodostettua vielä syvällisempi ymmärrys siitä, mistä johtajan ja johdettavan välisessä suhteessa tarvittavassa vuorovaikutusosaamisessa on kyse ja missä määrin johtajan vuorovaikutusosaaminen on johtajan osaamista ja missä määrin relationaalista. 
Tutkittavaa ilmiötä olisi voitu myös tutkia vertailevan tapaustutkimuksen tavoin sen sijaan, että tarkasteltiin yhden kohdeorganisaation johtajia. Arvioisin kuitenkin saavuttaneeni yksityiskohtaista aineistoa ja onnistuneeni luomaan uutta tietoa tähän asti jokseenkin vähän tutkitusta ilmiöstä. Jatkossa olisi mielenkiintoista syventää sen tarkastelua, millaista vuorovaikutusosaamista tietoperustaisen työn johtajat ja millaista suoritusperustaisen työn johtajat tarvitsevat. Tutkimus voisi kohdistua myös tietoperustaisen työn erilaisiin vuorovaikutuskäytänteisiin, esimerkiksi itseohjautuvien tiimien toimintaan, kollektiivisiin käytäntöihin ja verkostoihin.

Arviointitutkimukseen ja viestintäkoulutuksen vaikuttavuuden osoittamiseen ja todentamiseen liittyy monenlaisia haasteita. Tutkimuksen menetelmävalintoja voidaan kritisoida siitä, että fokusryhmä-keskusteluissa ei päästy syvälle johtajien vuorovaikutusosaamisen arvioinnissa. Tutkimusongelmaa johtajan vuorovaikutusosaamisen kehittymisestä olisi voitu lähestyä toisenlaisin menetelmin esimerkiksi haastattelemalla johtajia yksitellen myös viestintäkoulutuksen jälkeen. Näen kuitenkin, että keskustelujen avulla saavutettiin kokonaiskuva koulutukseen osallistuneiden henkilöiden käsityksistä johtamisviestintäkoulutuksesta ja opitun siirrettävyydestä käytäntöön. Lisäksi tutkimus nosti esiin niitä haasteita, joita vaikuttavuuden arviointiin liittyy. Jatkossa olisikin mielenkiintoista kehittää uudenlaisia vaikuttavuuden arviointiasetelmia.

Jatkotutkimuksessa voitaisiin selvittää myös sitä, miten johtajan ja johdettavan väliseen vuorovaikutussuhteeseen liittyvää osaamista voidaan kehittää. Olisi olennaista keskittyä siihen, millaisin mekanismein ja menetelmin vuorovaikutusosaaminen kehittyy, millaiset tekijät johtavat tietojen karttumiseen ja taitojen kehittymiseen sekä siihen, miten viestintäkoulutuksessa voidaan tukea sellaisten tietojen ja taitojen kehittymistä, jotka auttavat siirtämään viestinnästä opittua käytäntöön.

Emme vielä tiedä, millaisessa ympäristössä tulemme työskentelemään tulevaisuudessa. Työelämän muutoksesta on kuitenkin tullut pysyvää. Vaikka organisaatioiden toimintamallit ja johtamiskäytännöt muuttuvat, työntekijöiden välinen vuorovaikutus pysyy yhtenä organisaatioiden tärkeimmistä prosesseista. Organisaatioiden työntekijöiden keskinäisen vuorovaikutuksen ja vuorovaikutussuhteiden laatu vaikuttaa niin organisaatioiden tuloksellisuuteen kuin työntekijöiden hyvinvointiin. Vuorovaikutussuhteet ja taitava toiminta niissä ovat avainasemassa siinä, miten nyky-yhteiskunnan ja tulevaisuuden työssä menestytään ja jaksetaan. Tieteellisen tutkimuksen on vastattava siihen, miten näitä suhteita ja niissä tarvittavaa kompetenttia viestintää voidaan tukea ja kehittää. Vuorovaikutusosaamisen tutkimus tarjoaa tähän hyvän näkökulman.

Rouhiainen-Neunhäuserer, M. 2009. Johtajan vuorovaikutusosaaminen ja sen kehittyminen. Johtajan viestintähaasteet tietoperustaisessa organisaatiossa. Jyväskylä Studies in Humanities 128. Jyväskylän yliopisto. 